\title{
EFFECT OF DIFFERENT SOWING DATES ON THE GRAIN YIELD AND SOME YIELD CHARACTERISTICS OF TEFF [Eragrostis teff (Zucc.) Trotter]
}

\author{
Hakan GEREN ${ }^{1 *}$, Tugce OZDOGAN CAVDAR ${ }^{1}$, Aleksandar SIMIC ${ }^{2}$, Zeljko S. DZELETOVIC \\ ${ }^{1}$ Ege University, Faculty of Agriculture, Dept. of Field Crops, Bornova, Izmir, TURKEY \\ ${ }^{2}$ Belgrade University, Faculty of Agriculture, Nemanjina 6, Zemun-Belgrade, SERBIA \\ ${ }^{3}$ Belgrade University, Institute for Application of Nuclear Energy, Belgrade, SERBIA \\ *Corresponding author: hakan.geren@ege.edu.tr
}

Received: 08.06.2020

\begin{abstract}
This research was carried out to determine the potential of teff as a staple crop for the Mediterranean climate during 2015 and 2016. The effects of four different sowing dates (15 April, 15 May, 15 June and 15 July) on the grain yield and some yield characteristics were investigated. The teff genotype "Dessie" was used as plant material and plant height, thousand-grain weight, harvest index and grain yield were tested. Two-year average results indicated that there were significant differences in mentioned characteristics among the sowing dates. Delayed sowing dates reduced the grain yield. The highest total grain yield, $2780 \mathrm{~kg} \mathrm{ha}^{-1}$, was obtained for the teff seeds sown on the $15^{\text {th }}$ April under Mediterranean ecological conditions.
\end{abstract}

Keywords: Grain yield, Mediterranean climate, sowing date, teff

\section{INTRODUCTION}

Teff or lovegrass as a field crop is an ancient staple crop for human consumption and originates from Ethiopia dating back to 4000 BC to 1000 BC (Eckhoff et al., 1993; Ketema, 1997). Similarly, it is an annual dual-purpose cereal crop grown in Australia, India, and South Africa as a forage crop (Costanza et al., 1979). It $(2 \mathrm{n}=40)$ is a self-pollinated, warmseason grass that uses the $\mathrm{C}_{4}$ photosynthetic pathway (Miller, 2010). It belongs to the family Poacea, subfamily Eragrostoidae, tribe Eragrosteae and genus Eragrostis. There are about 350 Eragrostis species of which E. teff is the only species cultivated for human consumption. In the systematic, varieties of its are classified according to grain colour, plant habitus, inflorescence and form of spike clusters, but only grain colours (white, red/brown and mixed) in commercial marketing. The oval-shaped its grain is not glume like wheat or rye. It is the grain of the smallest grain size (less than $1 \mathrm{~mm}$ ) in the world. A thousand-grain weight is usually 200-400 milligrams (NRC, 1996; Ketema, 1997). Unlike other cereals, the seeds of teff are gluten-free and they are considered a rich source of proteins and nutrients, which can be used as an alternative food source for people with celiac disease and diabetes (Spaenij-Dekking et al., 2005). It is an excellent food security crop because it is highly resistant to various biotic and abiotic stresses (Dereje et al., 2018). Teff possesses desirable storage properties without losing viability since the grains are resistant to storage pests compared to the other cereals under the local storage conditions.
One of the key components of plant production is the determination of the sowing date (Atis and Akar, 2018; Temel and Yolcu, 2020). To obtain high yield and quality products in teff cultivation, it is very important to determine the most adequate growing period where the plant could reach physiological maturity by selecting the most suitable cultivar. Many researchers have overemphasized the effect of sowing time on the grain yield of its. As it is well known, Ethiopia is the origin and centre of diversity for teff (Tefera et al., 1990). Several experiments suggest that, depending on the location and maturity period of the cultivar, it is grown during the main growing season between June and November for teff growth and development under ecological conditions of Ethiopia (Ketema, 1997). Based on a planting date study conducted in Kentucky and Virginia from May to July, planting from June to July was found to be the optimum time for teff plants (Abaye et al., 2006). Dent and Reid (2009) have reported that optimum planting dates for teff grown in South Tasmania range from mid-October to late December and grain yield would be lower for planting before or after that critical time. Kebede (2012) reported that teff could be planted from late May to the beginning of August with even erratic rainfall. Zucca (2016) explored the significant effect of different sowing dates $(2,9,16,23$ and 30 July) on days to heading, days to maturity, plant height, number of tillers per plant, grain yield of teff.

Teff is a newly introduced plant to Turkey, and therefore, knowledge on the productivity and yield of the teff crop 
under the intensive farming management in the Mediterranean environment has not been well documented so far. Hence, this paper aims to investigate the relationship between yield and yield contributing characters of teff regarding the sowing date under Mediterranean climatic conditions.

\section{MATERIALS AND METHODS}

Site and weather

A field experiment was conducted in two consecutive growing seasons (2015 and 2016) on a private farm in Soke-
Aydin, located about $35 \mathrm{~m}$ above sea level with typical Mediterranean climate conditions (Table 1). The experimental area is located in the Mediterranean zone of the country with temperate and rainy winters and hot and dry summers. The soil had sandy texture $(80.1 \%$ sand, $1.8 \%$ clay and $18.1 \%$ silt) with a $\mathrm{pH}$ of 7.2 , organic matter $1.27 \%$, salt $0.05 \%$, total $\mathrm{N} 0.06 \%$, available phosphorus $2.54 \mathrm{mg} \cdot \mathrm{kg}^{-1}$ and available potassium $403 \mathrm{mg} \cdot \mathrm{kg}^{-1}$. There are no limiting factors for the establishment and growth of the teff crop in climate and soil conditions of the experimental site.

Table 1. Some meteorological datas of the experimental area at Soke/Turkey in 2015 and 2016.

\begin{tabular}{lcccccc}
\hline & \multicolumn{2}{c}{ Average air temperature $\left({ }^{\circ} \mathbf{C}\right)$} & \multicolumn{2}{c}{ Total precipitation $(\mathbf{m m})$} \\
\cline { 2 - 7 } Months & $\mathbf{2 0 1 5}$ & $\mathbf{2 0 1 6}$ & LYA & $\mathbf{2 0 1 5}$ & $\mathbf{2 0 1 6}$ & LYA \\
\hline April & 15.1 & 19.4 & 15.9 & 28.2 & 8.3 & 54.0 \\
May & 21.7 & 20.6 & 21.1 & 100.7 & 37.5 & 36.2 \\
June & 24.3 & 27.9 & 26.2 & 8.9 & 4.3 & 11.6 \\
July & 29.1 & 29.7 & 28.7 & 3.0 & - & 6.8 \\
August & 29.1 & 28.0 & 27.7 & - & - & 5.6 \\
September & 25.8 & 24.3 & 23.2 & 27.0 & 22.8 & 14.3 \\
October & 20.0 & 19.7 & 18.6 & 68.9 & 20.0 & 41.1 \\
November & 15.0 & 13.9 & 13.1 & 85.5 & 51.4 & 92.6 \\
\hline X- $\Sigma$ & 22.4 & 22.9 & 21.8 & 322.2 & 144.3 & 262.5 \\
\hline
\end{tabular}

LYA: Long year average (20 years), X: Mean, $\Sigma$ : Total

\section{Experimental treatments and design}

The Dessie teff cultivar from South Idaho/USA was used as crop material. Four different dates of sowing (15 th $^{\text {th }}$ pril, $15^{\text {th }}$ May, $15^{\text {th }}$ June and $15^{\text {th }}$ July) were employed in a Randomized Complete Block Design with three replications. Experimental plots were $10.5 \mathrm{~m}^{2}(5 \mathrm{~m} \times 2.1 \mathrm{~m})$, having 12 rows with a row spacing of $17.5 \mathrm{~cm}$. Seeds were sown by hand at a depth of $1 \mathrm{~cm}$ on all sowing times at a rate of $20 \mathrm{~kg}$ $\mathrm{ha}^{-1}$ (Twidwell et al., 1991). The overhead sprinkler system was installed in the field during both growing seasons. The soil was cultivated before sowing, $50 \mathrm{~kg} \mathrm{ha}^{-1}$ of nitrogen (urea form) and $50 \mathrm{~kg} \mathrm{ha}^{-1}$ of $\mathrm{P}_{2} \mathrm{O}_{5}$ were applied before the soil was cultivated again to produce a seedbed suitable for planting and the rest of nitrogen $\left(50 \mathrm{~kg} \mathrm{ha}^{-1}\right)$ in the form of $\left(\mathrm{NH}_{4}\right)_{2} \mathrm{SO}_{4}$ was applied at 30-40 cm plant height (Arefaine, 2013; Giday et al., 2014). No herbicides were used to control weeds. The weeds were controlled by three hoe weeding regimes throughout the experiment. No diseases or pests were observed in teff plants during the trial.

\section{Measurements}

Plants were harvested at the physiological maturity stage ( $\sim 13 \%$ moisture) from mid-August to late November in both years (Table 2), collecting the middle 10 rows of plots in order to avoid border effects (Net: $8.75 \mathrm{~m}^{-2}$ ). In each plot, cuttings were made with a hand-sickle at $5 \mathrm{~cm}$ above the ground level. The samples were dried under shaded-open conditions for one week, after which the dried samples were threshed by a seed threshing machine. In the study, the following characteristics were investigated (Arefaine, 2013): number of plants at grain harvest (plant $\mathrm{m}^{-2}$ ): The plants in the quadrate of $1 / 2$ square meter $(50 \times 100 \mathrm{~cm})$ put in two different sites of the plot before harvesting were counted. Plant height $(\mathrm{cm}): 10$ plants from the ground level to the top of the stem at the time of harvesting were measured. Panicle length $(\mathrm{cm})$ : the panicle of each selecting plant was measured from the node (the first panicle branch started) to the tip of the panicle. Thousand-grain weight $(\mathrm{mg})$ : the grains were taken from each plot and 1000 grains were counted by hand and then weighed. Biological yield $\left(\mathrm{kg} \mathrm{ha}^{-1}\right)$ : after the harvesting, total above-ground biomass (with grains) was measured. Grain yield $\left(\mathrm{kg} \mathrm{ha}^{-1}\right)$ : the grains of all the crops of each separated plot were weighed and the grain yield/plot was then converted to $\mathrm{kg}$ per hectare. Harvest index (HI, \%): this was calculated by the following formula: HI: (grain yield) / (biological yield).

\section{Statistical analysis}

All data were subjected to analysis of variance (ANOVA) using the Statistical Analysis System (SAS, 1998). The Least Significant Difference (LSD) test at $\mathrm{P} \leq 0.05$ was used to separate means whenever there were significant differences (Stell et al., 1997). 
Table 2. Sowing and harvesting dates in the field experiment

\begin{tabular}{ccccc}
\hline & \multicolumn{2}{c}{$\mathbf{2 0 1 5}$} & \multicolumn{2}{c}{$\mathbf{2 0 1 6}$} \\
\cline { 2 - 5 } Sowing dates & $\mathbf{1}^{\text {st }}$ harvest & $\mathbf{2}^{\text {nd }}$ harvest & 1 $^{\text {st }}$ harvest & 2 harvest $^{\text {na }}$ \\
\hline 15 April & $12 / 08$ & $10 / 11$ & $14 / 08$ & $21 / 11$ \\
15 May & $18 / 08$ & $15 / 11$ & $21 / 08$ & $27 / 11$ \\
15 June & $29 / 08$ & $21 / 11$ & $1 / 09$ & $27 / 11$ \\
15 July & $5 / 09$ & $21 / 11$ & $9 / 09$ & \\
\hline
\end{tabular}

\section{RESULTS AND DISCUSSION}

The number of plants at harvest, plant height, panicle length, thousand-grain weight, biological yield, grain yield and harvest index were significantly affected by sowing dates during both years (Table 3 ). The year had a significant effect on the majority of tested characteristics, except for, the number of plants and harvest index in the experiment. The year $\mathrm{x}$ sowing date interactions were significant for the number of plants, panicle length and harvest index.
Number of plants

The number of plants at grain harvest was affected by the year $\mathrm{x}$ sowing date interaction (Table 3 ). The maximum number of plants being 2574 plant $\mathrm{m}^{-2}$ was recorded on the $15^{\text {th }}$ April in 2016 and the minimum number of plants (1593 plants $\mathrm{m}^{-2}$ ) was recorded on the $15^{\text {th }}$ July in 2016 .

Table 3. The means of grain yields and some yield characteristics of teff crop at different sowing dates

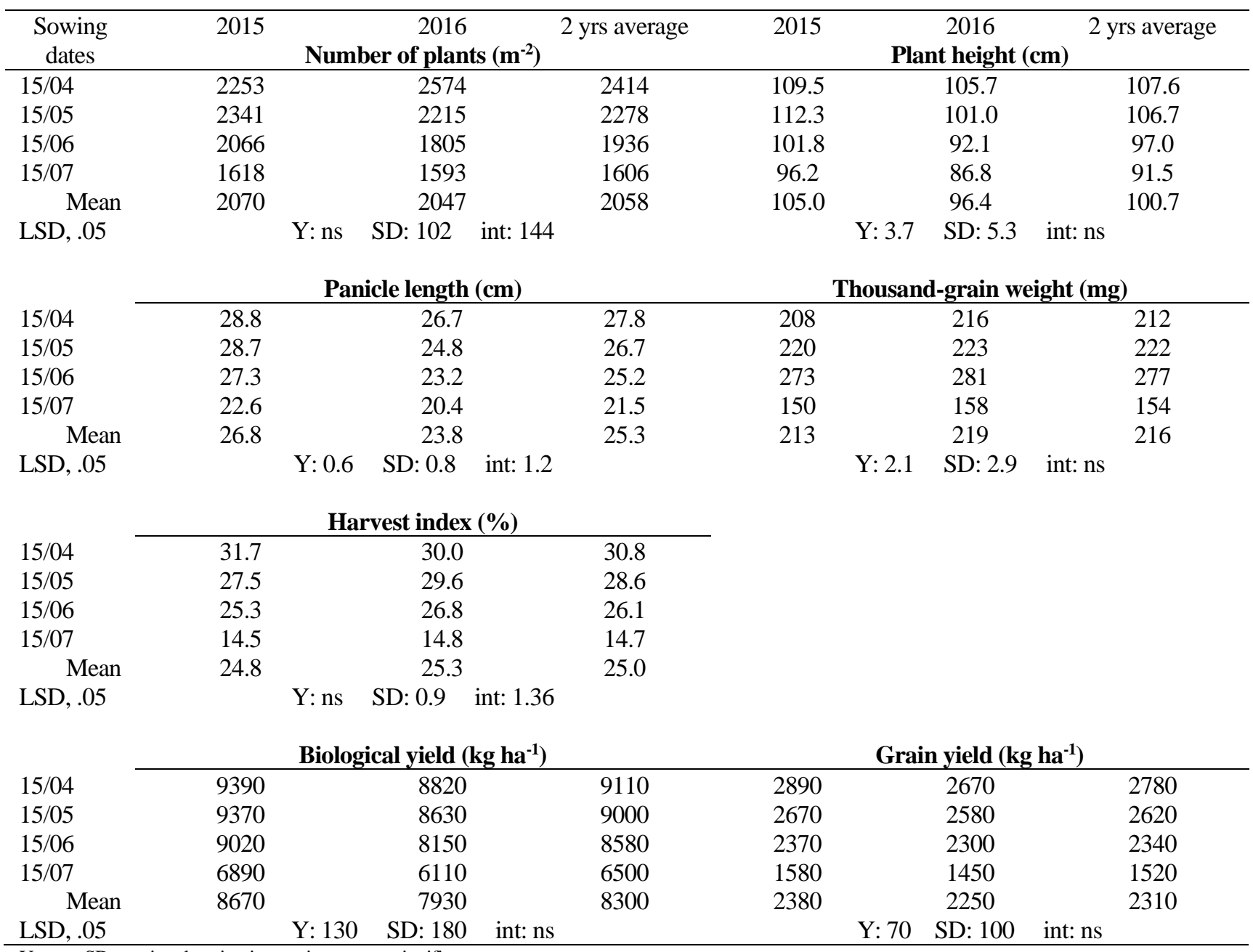

Y: year, SD: sowing date, int: interaction, ns: not significant

The delaying of sowing date (from mid-April to midJuly) decreased the number of plants in both experimental years. Hence, prolonged growing season causes more plant numbers. This could be associated with the facts that rising temperatures and weed competition in late sowings (mid-
June and July) was the main effect on the decreasing number of plant. In North Gondar, Ethiopia, Zucca (2016) reported that differences among the sowing dates with regard to the number of tillers per plant were highly significant. It was stated that the number of tillers per plant of teff was affected 
by the sowing date from early July to late July being 3.8 per plant to 6.9 per plant (Zucca, 2016). Similar results have been reached in research by Geren et al. (2019), with the highest number of teff plants (1734 plants $\mathrm{m}^{-2}$ ) obtained from the sowing date of mid-April and at $17.5 \mathrm{~cm}$ row spacing under typical Mediterranean climatic conditions. Tefera et al. (1990) concluded that productive tillers were positively associated with the grain yield of teff under the Ethiopian ecological conditions. In the present study, the delaying sowing date caused the decreasing of the plant number per unit area. In addition, it is widely known that the number of plants at grain harvest reacts positively and directly with the grain yield (Vandercasteelen et al., 2014).

\section{Plant height}

ANOVA results showed that plant height was significantly affected by sowing date and year, but the interaction had no significant effect on plant heights (Table $3)$. The highest plant height $(107.6 \mathrm{~cm})$ was obtained on the $15^{\text {th }}$ April, which was followed by the $15^{\text {th }}$ May $(106.7 \mathrm{~cm})$. However, there was no statistical difference between April and May. The lowest plant height was determined in planting on the $15^{\text {th }}$ July being $91.5 \mathrm{~cm}$. There were significant differences between the two years in terms of plant height. The average plant height of the first year $(105.0 \mathrm{~cm})$ was higher than that of the second year $(96.4 \mathrm{~cm})$ (Table 3). Variability of precipitation recorded during the trial years (Table 1) caused this result.

In experimental conditions, the delaying of sowing date in teff crops led to a decrease in plant height in both years This can be a result of the shortened vegetative growth period available to the crop plants due to changes in the photoperiod that enhanced the rate of development towards the reproductive phase (Assefa et al., 2015). Plant height is a crucial growth characteristic directly linked with the productive potential of plants with regard to the grain yield (Miller et al., 1991). Mengistu et al. (2001), in the trials with 2 locations (Kobo and North Wallo, Ethiopia) and three different sowing dates (10 days before common sowing date, common sowing date and 10 days after common sowing date), found that plant height of teff was negatively affected by the 10-day delay. They also stated that all of the traits were considered due to the main effect of sowing date on both experimental sites. Juraimi et al. (2009) investigated different sowing dates (SDs) on teff plants (the $1^{\text {st }}$ SD [the second week of July], the $2^{\text {nd }}$ SD [delayed by 7 days after the $1^{\text {st }} \mathrm{SD}$ ] and the $3^{\text {rd }} \mathrm{SD}$ [delayed by 15 days after the $1^{\text {st }} \mathrm{SD}$ ], respectively). They reported that plant height decreased by delaying sowing dates $(89,84$ and $78 \mathrm{~cm}$, respectively). There was a relationship among plant height, biomass and grain yield, where grain yield responded positively to taller plants and higher biomass when the crop was sown early in the season (Juraimi et al., 2009; Zucca, 2016).

In addition to that, lodging is a major problem in teff cultivation in all environments. Lodging substantially reduces the yield and quality of both the grain and straw of teff productivity. Lodging or the permanent displacement of the stem from the upright position is the major constraint limiting the productivity of the crop, especially when it occurs during the grain-filling period (Ketema, 1993). Similarly, many researchers have emphasized that planting at narrow row spacing can reduce lodging (Hundera et al., 1999; Berry et al., 2004; Mebratu et al., 2016). In our study, although the plants were sown at $17.5-\mathrm{cm}$ row spacing, partial lodging was observed in the plots. However, lodging was not scored in this study.

\section{Panicle length}

Year effect was also significant, and average teff panicle length of the first year $(26.8 \mathrm{~cm})$ was higher than that of the second year $(23.8 \mathrm{~cm})$ due to higher total precipitation in the first year (Table 1). The year x sowing date interaction was significant for the panicle length (Table 3). The highest panicle length $(28.8 \mathrm{~cm})$ was obtained on the $15^{\text {th }}$ April in 2015 , whereas the lowest was $20.4 \mathrm{~cm}$ on the $15^{\text {th }}$ July in 2016.

The panicle length of teff decreased noticeably with the late sowing (the $15^{\text {th }}$ July) in both trial years. Some of the previous researchers recommended early sowing for high panicle length during production seasons (Sherif, 2004; Juraimi et al., 2009; Zucca, 2016), and they also stated that an increase in panicle length was a corresponding increase in teff grain yields, provided that there was no delay in sowing. In the experiment, panicle length of the first 2 sowing dates (15 April and 15 May) increased depending on day-length, but then in the case of later sowing date (15 June and 15 July), the panicle length of teff plant decreased due to the shorter day-length and increasing temperature until September (Table 1), since teff is a short-day plant (Vos et al., 2013). In the teff plants, Dawit and Andnew (2005) explained a positive correlation between grain yield and panicle length. The results indicating panicle lengths of teff crop were in an agreement with those of many researchers (Abebe and Workayehu, 2015; Mebratu et al., 2016; Abebe and Filmon, 2018).

\section{Thousand-grain weight}

ANOVA results showed that thousand-grain weight was significantly affected by sowing date and year, but not by the interaction. The year effect was also significant for this feature and the average value in the first year $(213 \mathrm{mg}$ ) was lower than in the second year $(219 \mathrm{mg})$. Thousand-grain weight significantly increased with the delay in sowing date from the $15^{\text {th }}$ April to the $15^{\text {th }}$ July. The heaviest grains (277 $\mathrm{mg}$ ) were produced in plots sown on the $15^{\text {th }}$ June and, thousand-grain weight on the $15^{\text {th }}$ April, $15^{\text {th }}$ May and $15^{\text {th }}$ July were not statistically at par with each other (Table 3). Numerically, the least grain weight $(154 \mathrm{mg})$ was obtained when teff was sown on the $15^{\text {th }}$ July.

In the present study, delaying sowing dates (from midApril to mid-July) caused a limited but significant increase in thousand-grain weight in the first harvest in both growing seasons. Nevertheless, we did not obtain any grain from the second harvest of mid-July sowing in the experimental area, therefore, the means of thousand-grain weights were lower. This might be due to the fact that under later sowing conditions the grains were forced to mature and dry because of the abrupt change in temperature (daytime-nighttime 
temperature differences) coupled with hard wind. Thus, the grains obtained from the $15^{\text {th }}$ July sown crop were small and ultimately resulted in lower test weight. On the other hand, the timely sown crop took advantage because after having completed its vegetative growth satisfactorily it came in the grain-filling stage when the temperature was quite favourable. Results from experiments have shown that the change of temperatures in October-November probably caused the negative effect on teff flower pollination in late sowing date. In addition, thousand-grain weight increased due to the decrease of fertile inflorescence per plant. Many researchers (Kebede, 2012; Asefa et al., 2014; Giday et al., 2014) reported that timely sowing gave higher thousandgrain weight as compared to delayed sowing. However, Geren et al. (2014) investigated different sowing dates $\left(1^{\text {st }}\right.$ March, 15 th $^{\text {th }}$ arch, $1^{\text {st }}$ April, 15 ${ }^{\text {th }}$ April, $1^{\text {st }}$ May and $15^{\text {th }}$ May) on the quinoa plant and found out that the thousandgrain weight decreased with late sowings.

\section{Harvest index}

The highest harvest index (31.7\%) was found in the first year in the case of the sowing on the $15^{\text {th }}$ April, whereas the lowest harvest index $(14.5 \%)$ was in the first year for the sowing on the $15^{\text {th }}$ July (Table 3 ). The year effect was not significant; there was a significant effect of year $\mathrm{x}$ sowing date interactions on the harvest index of teff.

In the experiment, the harvest index decreased comprehensibly with late sowing in both trial years. As it is widely known, harvest index is used in agriculture to quantify the yield of a crop species versus the total amount of biomass that has been produced (Abebe and Filmon, 2018). Therefore, harvest index may vary by agronomic practices (Bhargava et al., 2007) such as sowing date, plant density, fertilization and irrigation, etc. Vos et al. (2013) stated that there was no significant difference among teff cultivars and sowing dates ( $28^{\text {th }}$ April and the $16^{\text {th }}$ May) in terms of harvest index, and the average was 9.5\%. Assefa et al. (2001) emphasized that the harvest index in teff varieties ranges from $5 \%$ to $39 \%$. Geren et al. (2019) reported the average harvest index of teff crops was $22 \%$ in mid-April sowings. However, our results are different as compared to the report of Mengistu et al. (2001), who reported that harvest index increased significantly as sowing was delayed.

\section{Biological yield}

The year effect was also significant for this treat and the average value in the first year $\left(8670 \mathrm{~kg} \mathrm{ha}^{-1}\right)$ was higher than in the second year $\left(7930 \mathrm{~kg} \mathrm{ha}^{-1}\right)$ (Table 3$)$. The highest biological yield was recorded for the first sowing date $(9110$ $\mathrm{kg} \mathrm{ha}^{-1}$ ) and the lowest biological yield was recorded for the last sowing date $\left(6500 \mathrm{~kg} \mathrm{ha}^{-1}\right)$. In addition, there was no statistical difference between April $\left(9110 \mathrm{~kg} \mathrm{ha}^{-1}\right)$ and May (9000 kg ha ${ }^{-1}$ ) sowings time in terms of biological yield. The sowing date $\mathrm{x}$ year interaction was not significant for the biological yield.

Delaying of sowing time caused a decrease in biological yield. A single year field experiment at Alem Tena (Central Ethiopia) showed that when sowing dates were delayed by 1 or 2 weeks, the biological yield was reduced by $35 \%$ (Juraimi et al., 2009). Contrarily, some studies in other countries showed that the sowing date had no effect on total biological yield (Vos et al., 2013). They claimed that no significant difference was determined between the $28^{\text {th }}$ April $\left(11.5 \mathrm{t} \mathrm{ha}^{-1}\right)$ and the $16^{\text {th }}$ May (11.4 $\mathrm{t} \mathrm{ha}^{-1}$ ) when total biological yield was compared. Roseberg et al. (2007), in Oregon, mentioned that the total biological yield increased (8627, 10728, 10927 and $12567 \mathrm{~kg} \mathrm{ha}^{-1}$ ) remarkably as sowing time was delayed (the $16^{\text {th }}$ May, the $30^{\text {th }}$ May, the $13^{\text {th }}$ June, and the $27^{\text {th }}$ June), respectively. On the other hand, Ketema (1993) has highlighted that sowing dates for teff in Ethiopia range from the $15^{\text {th }}$ to the $21^{\text {st }}$ July on light-textured soil and from the $21^{\text {st }}$ to the $31^{\text {st }}$ July on heavy soils. In line with these findings, our results are partially in accordance with these results.

\section{Grain yield}

The ANOVA results indicated that the grain yield was significantly affected by year, sowing date. The average grain yield in the first year $\left(2380 \mathrm{~kg} \mathrm{ha}^{-1}\right)$ was higher than in the second year (2250 $\mathrm{kg} \mathrm{ha}^{-1}$ ) (Table 3), most probably due to providing better humidity and precipitation for the maturation of crops in 2015 compared to 2016 (Table 1).According to two-year results, the maximum total grain yield $\left(2780 \mathrm{~kg} \mathrm{ha}^{-}\right.$ $\left.{ }^{1}\right)$ was recorded for plants established at the sowing date of the $15^{\text {th }}$ April. However, the minimum total grain yield (1520 $\mathrm{kg} \mathrm{ha}^{-1}$ ) was recorded for plants established at the sowing date of the $15^{\text {th }}$ July. The year effect was also significant.

Delaying of sowing time consistently decreased the grain yield. In other words, delays in sowing date also reduced yield components such as the number of plants per unit area, panicle length and the effective duration of grain filling compared with earlier sowings. It is reported that low temperature reduced grain yield as a result of a reduction in basal tiller numbers, grain number and individual grain weight (Fussell and Norman, 1980; Ong and Squire, 1984). In the present study, it was also found that $80 \%$ of the total yield was obtained from the first harvest. In both years, teff grain yield could not be obtained in the second harvest of the crop, which was sown late (on the $15^{\text {th }}$ July) under the experimental area conditions. This indicates that regrowth after grain harvest can also be used as a different alternative like grazing.

Grain yield per unit area is a function of the integrated effect of the yield components that are affected differently by growing conditions (Khan et al., 2000). Sherif (2004) reported a similar relationship among different sowing dates $(15,22$ and 28 July) for grain yield of teff. When sowing was delayed for 7 and 15 days, grain yields were reduced by $60 \%$ and $68 \%$, respectively. Mengitsu et al. (2001) informed that early sowing in teff cultivation affect positively grain yield at the rate of $19 \%$ compared with late sowing. In addition, Juraimi et al. (2009) wrote that timely sown teff produced $18 \%$ and $19 \%$ higher yield compared to sowing delayed for 7 and 15 days, respectively. Conversely, Dent and Reid (2009) expressed that teff grain yield increased $(54,119,610,1168$ and $94 \mathrm{~kg} \mathrm{ha}^{-1}$ ) with the delaying sowing dates but later decreased $\left(12^{\text {th }}\right.$ October, $25^{\text {th }}$ October, $11^{\text {th }}$ November, $22^{\text {th }}$ November, $7^{\text {th }}$ December, respectively) in South Tasmania. Vos et al. (2013) conducted a field experiment in 
Wageningen (Netherland), in 2006 for two sowing dates (April $28^{\text {th }}$ and May $16^{\text {th }}$ ) with four teff cultivars. They found that there was no difference in grain yield among cultivars and between the $28^{\text {th }}$ April (1075 $\left.\mathrm{kg} \mathrm{ha}^{-1}\right)$ and the $16^{\text {th }}$ of May $\left(1068 \mathrm{~kg} \mathrm{ha}^{-1}\right)$.

\section{CONCLUSION}

The objective of the study was to determine the optimal teff planting date for maximising grain production. The vast agro-climatic variation among teff producing countries and the seasonal difference within regions do not allow the allocation of a specific date of sowing. The experiment has shown that the influence of sowing date on grain yield is mainly due to day-length and temperature differences that are associated with delaying the planting from April to July. Maximum total grain production was achieved from the $15^{\text {th }}$ April planting, which gave yields of $2780 \mathrm{~kg} \mathrm{ha}^{-1}$ for the $2015 / 2016$ season. As a conclusion, the $15^{\text {th }}$ April can be recommended as a suitable sowing date in terms of maximum grain production under Mediterranean-type ecological climate conditions.

\section{LITERATURE CITED}

Abaye, A.O., C. Teutsch, W. Clapham and T. Phillips. 2006. The influence of nitrogen rates, planting dates, and seeding rates on herbage biomass and nutritive values of Teff (Erogrostis tef (Zucc.)). The ASA-CSSA-SSSA International Annual Meetings 12-16 November 2006 Indianapolis.

Abebe, A. and Y. Filmon. 2018. Effect of Seed Rate on Yield and Yield Components of Tef ((Eragrostic tef) Trotter) at Konso and Arbaminch, Southern Ethiopia. Journal of Natural Sciences Research 8(5):38-45

Abebe, B. and T. Workayehu. 2015. Effect of method of sowing and time of Di-Ammonium Phosphate (DAP) fertilizer application, on yield and yield components of Tef (Eragrostis tef Trotter) at Shebedino, Southern Ethiopia. Advances in Crop Science and Technology 3: 168

Arefaine, A. 2013. Effects of rates and time of nitrogen fertilizer application on yield and yield components of tef [Eragrostis tef (Zucc.) Trotter] in Habro District, Eastern Ethiopia. Haramaya University Department of Plant Sciences College of Agriculture and Environmental Sciences School of Graduate Studies MSc Thesis $77 \mathrm{p}$

Asefa, F., A. Debela and M. Mohammed. 2014. Evaluation of Teff [Eragrostis tef (Zuccagni) Trotter] responses to different rates of NPK along with Zn and B in Didessa District, Southwestern Ethiopia. World Applied Sciences Journal 32(11):2245-2249

Assefa, K., H. Tefera, A. Merker, T. Kefyalew and F. Hundera. 2001. Variability, heritability and genetic advance in pheno-morphic and agronomic traits of Tef [Eragrostis tef (Zucc.) Trotter] germplasm from eight regions of Ethiopia. Hereditas 134:103-113

Assefa K., G. Cannarozzi, D. Girma, R. Kamies, S. Chanyalew, S. Plaza-wüthrich, R. Blösch, A. Rindisbacher, S. Rafudeen and Z. Tadele. 2015. Genetic diversity in tef [Eragrostis tef (Zucc.) Trotter]. Frontiers in Plant Science 6:177-209.

Atis, I. and M. Akar. 2018. Grain yield, forage yield and forage quality of dual purpose wheat as affected by cutting heights and sowing date. Turkish Journal of Field Crops 23(1):38-48

Berry, P.M., M. Sterling, J.H. Spink, C.J. Baker, R. SylvesterBradley, S.J. Mooney, A.R. Tams, A.R. Ennos and L.S. Donald 2004. Understanding and reducing lodging in cereals. Advances in Agronomy 84:217-271
Bhargava, A., S. Shukla and D. Ohri. 2007. Genetic variability and interrelationship among various morphological and quality traits in quinoa (Chenopodium quinoa Willd.). Field Crops Research 101:104-116

Costanza, S.H., J.M.J. DeWet and J.R. Harlan. 1979. Literature review and numerical taxonomy of Eragrostis teff. Economic Botany 33:413-424

Dawit, W. and Y. Andnew. 2005. The study of fungicides application and sowing date, resistance, and maturity of Eragrostis tef for the management of teff rust [Uromyces eragrostidis]. Canadian Journal of Plant Pathology 27(4):521527

Dent, R. and R. Reid. 2009. Agronomic evaluation of teff in Tasmania, Australian Government, Rural Industries Research and Development Corporation. Project No: PRJ-007907 Pub No: $15 / 082,4 \mathrm{p}$

Dereje, G., D. Alemu, T. Adisu and B. Anbessa. 2018. Response of yield and yield components of Tef [Eragrostis tef (Zucc.) Trotter] to optimum rates of nitrogen and phosphorus fertilizer rate application in Assosa Zone, Benishangul Gumuz Region. Ethiopian Journal of Agricultural Sciences 28(1):81-94.

Eckhoff, J.L.A., D.M. Wichman, J. Scheetz, M. Majerus, L.E. Welty, G.F. Stallknecht, R.L. Ditterline, R.L. Dunn and D.C. Sands. 1993. Teff: a potential forage and grain crop for Montana. Montana AgResearch 10:38-41.

Fussell, L.K. and M.J.T Norman. 1980. Effect of temperature during various growth stages on grain development and yield of Pennisetum americanum. Journal of Experimental Botany 3:621-33

Geren, H., Y.T. Kavut and B. Kir. 2019. Effect of different row spacings on the yield and some yield characteristics of Teff (Eragrostis teff) crop grown under Soke ecological conditions. Journal of Agriculture Faculty of Ege University 56(2):231-239 (in Turkish)

Geren, H., Y.T. Kavut, G.D. Topcu, S. Ekren and D. Istipliler. 2014. Effects of different sowing dates on the grain yield and some yield components of quinoa (Chenopodium quinoa Willd.) grown under Mediterranean climatic conditions. Journal of Agriculture Faculty of Ege University 51(3):297-305 (in Turkish)

Giday, O., H. Gibrekidan and T. Berhe. 2014. Response of teff (Eragrostis tef) to different rates of slow release and conventional urea fertilizers in Vertisols of Southern Tigray, Ethiopia. Advances in Plants \& Agriculture Research 1(5):1-8

Hundera, F., E. Bechere and H. Tefera. 1999. Interrelationships of grain yield, lodging and agronomic traits in tef, Eragrostis tef. Tropical Science 39:63-69

Juraimi, A.S., M. Begum, A.M. Sherif and A.A. Rahim. 2009. Competition effects of date of sowing and nutsedge removal time on yield and yield contributing characters of tef [Eragrostis tef (Zucc.) Trotter]. American Journal of Applied Sciences 6(10):1820-1825.

Kebede, T. 2012. Response of Tef (Erogrostis tef (Zucc.) Trotter) cultivars to nitrogen and phosphorus fertilizer rates at Menzkeya district, North Shewa, Ethiopia. Haramaya University MSc Thesis 66p

Ketema, S. 1993. Tef (Eragrostis tef): breeding, genetic resources, agronomy, utilization and role in Ethiopian Agriculture Institute of Agricultural Research. Addis Abeba 102p

Ketema, S. 1997. Tef (Eragrostis tef (Zucc.) Trotter), Promoting the conservation and use of underutilized and neglected crops. 12. Institute of Plant Genetics and Crop Plant Research, Gatersleben/International Plant Genetic Resources Institute Rome Italy 50p

Khan, H., M.A. Khan, I. Hussain, M.Z. Khan and M.K. Khattak. 2000. Effect of sowing methods and seed rates on grain yield 
and yield components of wheat variety PAK-81. Pakistan Journal of Biological Science 3(7):1177-1179.

Mebratu, Y., C.V. Raghavaiah and H. Ashagre. 2016. Production potential of Tef (Eragrostis tef (Zucc.) Trotter) genotypes in relation to integrated nutrient management on vertisols of mid high lands of Oromia Region of Ethiopia, East Africa. Advances in Crop Science and Technology 4:6.

Mengistu, T.K., H.G. Kidan and K. Georgis. 2001. Effect of sowing date and nitrogen fertilization on yield and related traits of teff [Eragrosris teff (Zucc) Trotter] on Vertisols of Kobo Area. Orth Wollo Haramaya University Library and Information Services $\mathrm{p}: 10$

Miller, B.C., J.E. Hill and S.R. Roberts. 1991. Plant population effects on growth and yield in water- Sindh, seeded rice. Agronomy Journal 83:291-297

Miller, D. 2010. Teff Guide 3rd edition, http://www.calwestseeds.com.product/teff. (Accessed September 24 2012)

National Research Council (NRC). 1996. Lost Crops of Africa: Volume I: Grains, Washington DC The National Academies Press

Ong, C.K. and G.R. Squire. 1984. Response to temperature in a stand of pearl millet (Pennisetum typhoides S \& H), VII Final numbers of spikelets and grain. Journal of Experimental Botany $35: 1233$

Roseberg, R.J., B.A. Charlton and R.A. Shuck. 2007. Yield and forage quality of four Teff seed brands as affected by planting date and soil/air temperatures in the Klamath Basin. Klamath Basin Research and Extension Center pp:30-41

SAS Institute. 1998. INC SAS/STAT user's guide release 7.0 Cary NC USA.
Sherif, A.M. 2004. Competition effects of purple nutsedge (Cyperus rotundus L.) on growth and yield of tef (Eragrostis teff) in Ethiopia, Universiti Putra Malaysia, School of Graduate Studies $\mathrm{PhD}$ Thesis $234 \mathrm{p}$

Spaenij-Dekking, L., Y. Kooy-Winkelaar and F. Koning. 2005. The Ethiopian cereal tef in celiac disease. The New England Journal of Medicine 353:1748-1749.

Stell, R.G.D., J.A. Torrie and D.A. Dickey. 1997. Principles and Procedures of Statistics: A Biometrical Approach $3^{\text {rd }}$ ed INC NY Mc Graw Hill Book

Tefera, H., S. Ketema and T. Tesema. 1990. Variability and genetic advance in tef (Eragrostis tef) cultivars. Tropical Agriculture 67:317-320

Temel, S. and S. Yolcu. 2020. The effect of different sowing time and harvesting stages on the herbage yield and quality of quinoa (Chenopodium quinoa Willd.). Turkish Journal of Field Crops 25(1):41-49

Twidwell, E.K., A. Boe and D.P. Casper. 1991. Teff: a new annual forage grass for South Dakota. South Dakota State University. Brookings SD Coop Ext Serv Bulletin Ex 8071

Vandercasteelen, J., M.D. Regassa., B. Minten and A.S. Taffesse. 2014. Perceptions, Impacts and Rewards of Row Planting of Teff. Available at http://dx.doi.org/10.2139/ssrn.2530422

Vos, J., S.H.V. Delden and T.J. Stomph. 2013. Some ecophysiological characteristics of Tef, including mechanics of lodging. Achievements and Prospects of Tef Improvement. Proceedings of the Second International Workshop, November 7-9 2011, Debre Zeit Ethiopia pp: 141-160

Zucca, C. 2016. Response of tef row planting to sowing dates on the highland heavy clay soils. Technical Report of Experimental Activities. Project Agreement No 100202 